\title{
Thermohaline features of the subsurface cyclonic eddy in the south central Bay of Bengal during August 1999
}

\author{
P Madhusoodanan and V V James \\ Naval Physical and Oceanographic Laboratory, Kochi 682 021, India.
}

\begin{abstract}
Analysis of the spatial data collected along two sections of temperature and salinity from Chennai to $13^{\circ} \mathrm{N}$ and $87^{\circ} \mathrm{E}$ and back to Chennai onboard INS Sagardhwani during the Bay of Bengal Monsoon Experiment (BOBMEX) from 10th to 20th August 1999 revealed the presence of a prominent cyclonic eddy centered around $280 \mathrm{~km}$ away from the coast. Analysis of the dissipation rate of the cyclonic eddy from transect one to transect two and from the analysis of the TOPEX data, it may be inferred that the cyclonic eddy is possibly due to the presence of westward propagating Rossby waves in the Bay of Bengal.
\end{abstract}

\section{Introduction}

The Bay of Bengal, influenced by the unique seasonal reversing monsoons and transient cyclonic storms, is an area of intense air-sea interaction. Mesoscale features of the Bay of Bengal are more prominent during the summer monsoon. The major manifestation of the oceanic mesoscale features are eddies. Oceanic eddies are circulating water bodies and they are generally formed either by separation of a meander or due to the force exerted by the wind stress curl. Water converges/diverges at the center of the eddy resulting in downward/upward motion of water in the case of anticyclonic/cyclonic eddies. Hence, the vertical thermal sections show troughs and ridges in the isothermal patterns (Gopalan et al 2000). Information on oceanic eddies is important in many ocean and atmospheric studies like acoustic propagation, heat transport, delineating good/bad monsoons, identifying potential fishery zones etc. Observations in the Bay of Bengal are very meager to reveal these eddies (Shetye et al 1993; Sanilkumar et al 1997). Under the Indian Climate Research Programme (ICRP) Implementation Plan (1998) a field experiment called the Bay of Bengal Monsoon Experiment (BOBMEX) was planned with the specific aim to study the linkage between the ocean and atmosphere during the summer monsoon of 1999 . During the period from 10th to 20th August 1999, INS Sagardhwani made two spatial surveys along $13^{\circ} \mathrm{N}$ from $81^{\circ} \mathrm{E}$ to $87^{\circ} \mathrm{E}$. Initial results of the data collected during the above cruise are presented in this study.

\section{Data}

A spatial section along $13^{\circ} \mathrm{N}$ from $81^{\circ}$ to $87^{\circ} \mathrm{E}$ (10th-12th August 1999) was covered with stations separated by 30 nautical miles interval (transect one) and it was repeated after 4 days (16th18th August 1999) along the same track (transect two) (figure 1). Data were collected from all the stations using a mini-conductivity-temperaturedepth recorder and standard meteorological instruments.

\section{Results and discussion}

\subsection{Vertical sections (transects one and two)}

Vertical sections of temperature and salinity (figures 2 and 3) revealed many interesting features. Warmer $\left(28.75^{\circ} \mathrm{C}\right)$ and low saline waters

Keywords. Sagardhwani; BOBMEX; cyclonic eddy; TOPEX; Rossby wave. 


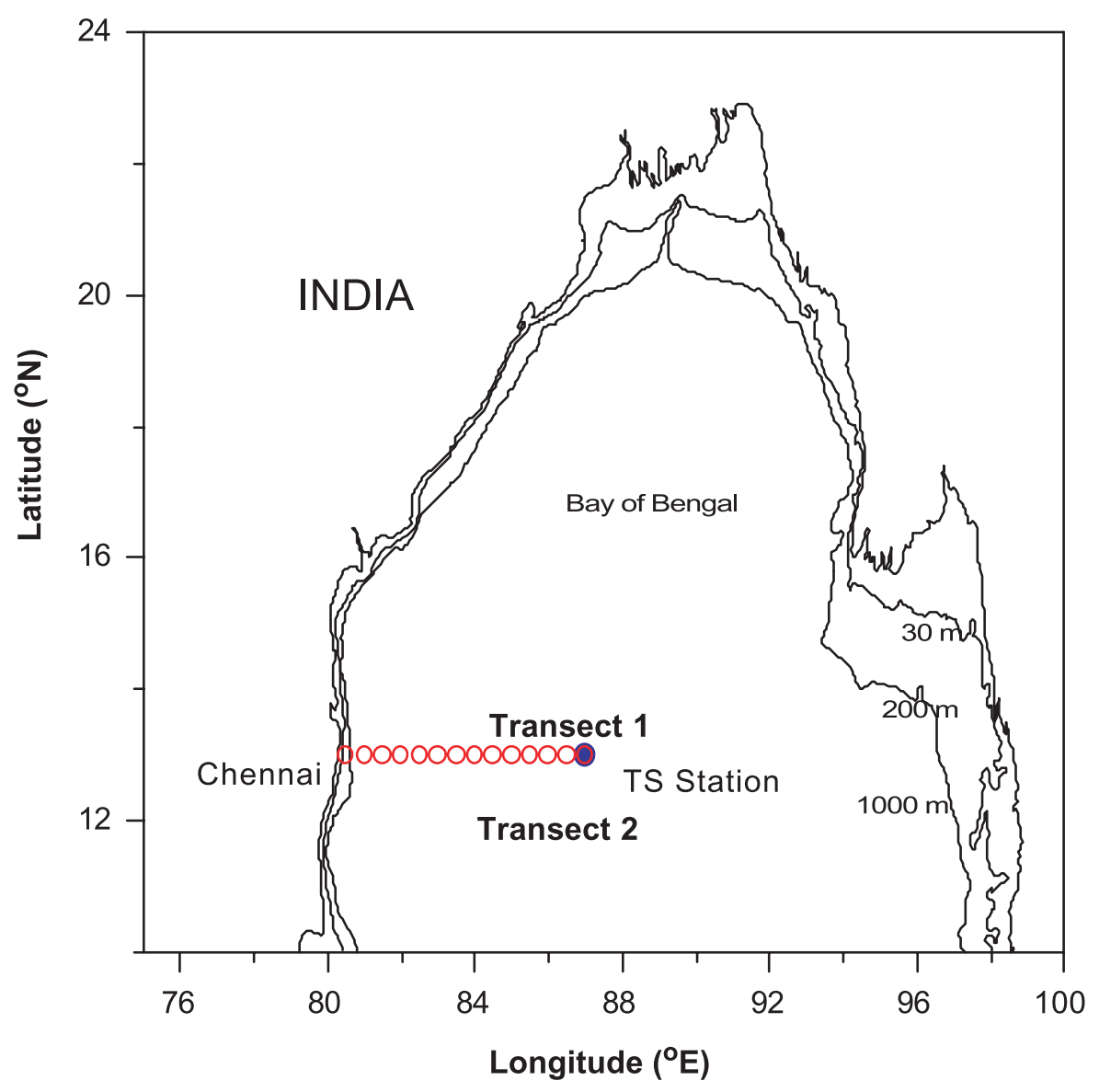

Figure 1. Station location map.

$(>33.8 \mathrm{PSU})$ are noticed in the surface. The central Bay of Bengal at $87^{\circ} \mathrm{E}$ appears to be warmer $\left(0.2-0.4^{\circ} \mathrm{C}\right)$ and more saline (0.85 PSU) compared to the western Bay. The sea surface salinity was around 33.2 PSU and increases towards the subsurface depths (figure 3). The mixed layer depth increased from $20 \mathrm{~m}$ near the Chennai coast to $60 \mathrm{~m}$ $200 \mathrm{~nm}$ offshore and shoaled to $30 \mathrm{~m}$ near $85^{\circ} \mathrm{E}$ and thereafter it deepened to $70 \mathrm{~m}$ around $87^{\circ} \mathrm{E}$ in transect one. Whereas in transect two, the mixed layer deepened from $20 \mathrm{~m}$ near the Chennai coast to $50 \mathrm{~m} 100 \mathrm{~nm}$ offshore and gradually shoaled to $40 \mathrm{~m}$ around $85^{\circ} \mathrm{E}$ and from there it increased $60 \mathrm{~m}$ at about $87^{\circ} \mathrm{E}$. Below the surface layer the isotherms and isohalines exhibit a downward slope from Chennai coast to $200 \mathrm{~nm}$ offshore in transect one and $100 \mathrm{~nm}$ offshore in transect two. The downward sloping of the isotherms indicates a northerly flow west of $83^{\circ} \mathrm{E}$ (Sanilkumar et al 1997). Another remarkable feature in this section is the presence of a ridge like structure centered around $280 \mathrm{~km}$ away from the coast in transect one, whereas it is slightly stretched in transect two. A strong halocline structure is noticed around $50 \mathrm{~m}$ depth and it shows a ridge pattern between 200 and $300 \mathrm{~km}$ away from the coast in transect one and a diffused ridge pattern in transect two. The erosion of $28^{\circ} \mathrm{C}$ isotherm west of this ridge in transect one indicates a temperature increase of $1^{\circ} \mathrm{C}$ per $1 \mathrm{~nm}$ and $1^{\circ} \mathrm{C}$ per $5 \mathrm{~nm}$ in transect two. The upslope of 34.2 isohaline showed an increase of $0.1 \mathrm{PSU}$ per $2 \mathrm{~nm}$ in transect one and $0.1 \mathrm{PSU}$ per $3 \mathrm{~nm}$ in transect two. The downslope of $28^{\circ} \mathrm{C}$ isotherm east of the ridge reveals a temperature decrease of $1^{\circ} \mathrm{C}$ per $1 \mathrm{~nm}$ in transect one and $1^{\circ} \mathrm{C}$ per $5 \mathrm{~nm}$ in transect two and 34.2 isohaline deepens $0.1 \mathrm{PSU}$ per $3 \mathrm{~nm}$ in both the transects. Water diverges at the center of the eddy resulting in the upward motion of water in the case of cyclonic eddy. Hence, the vertical thermal sections show ridge in the isothermal pattern (Gopalan et al 2000). When the upward motion of water occurs, it diverges at the surface, creating a depression at the surface because of the cold dense water at the surface. This can be seen from the upsloping of $28^{\circ} \mathrm{C}$ isotherm almost at the surface of the ocean at $13^{\circ} \mathrm{N}$ and $85^{\circ} \mathrm{E}$. Hence, the ridge structure may be interpreted as a cyclonic cold core eddy with a spatial scale of the order of $100-150 \mathrm{~km}$ as noticed in the thermal structure between 200 and $350 \mathrm{~km}$ 


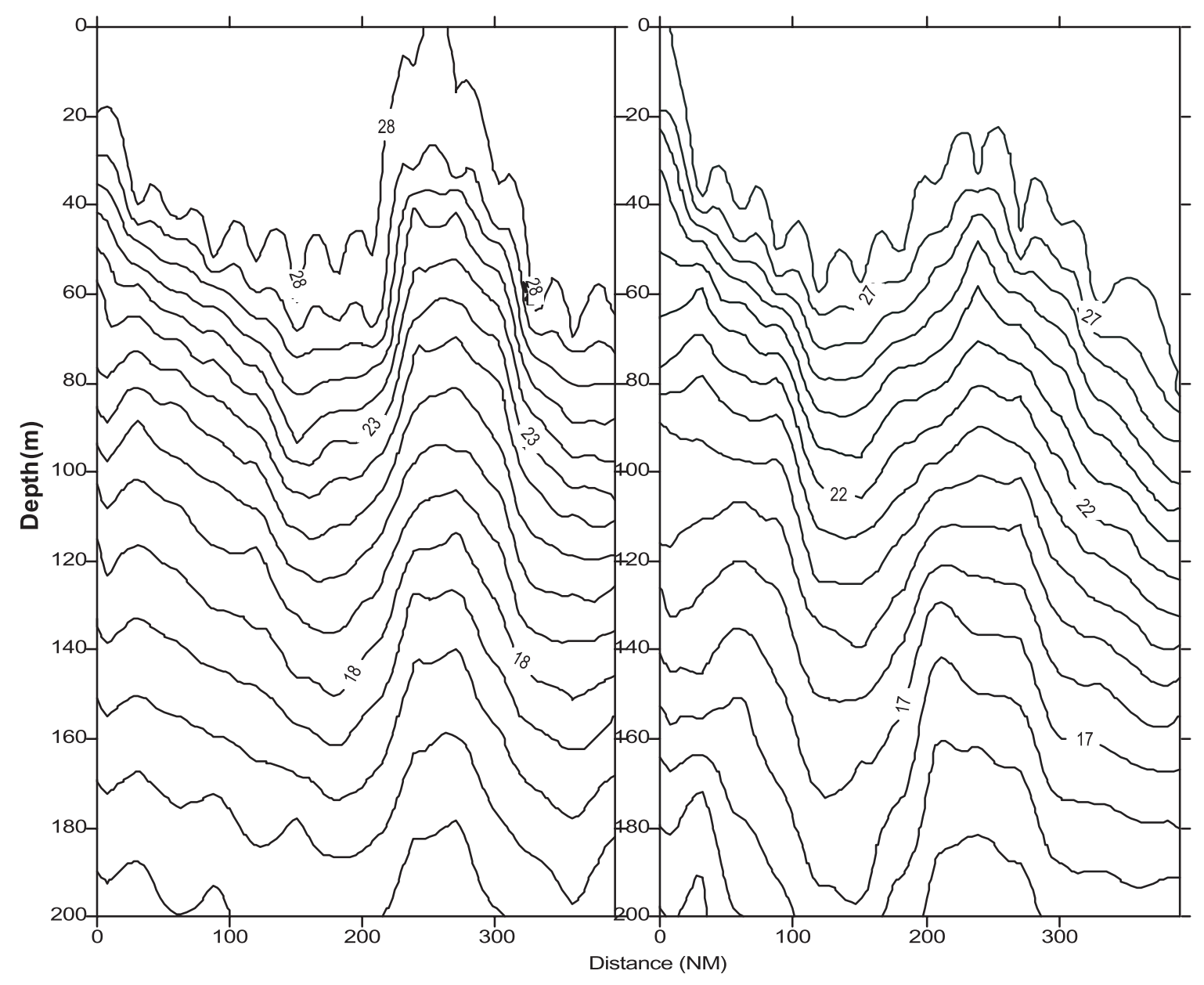

Vertical sections of temperature $\left({ }^{\circ} \mathrm{C}\right)$ along $13^{\circ} \mathrm{N}$ from Chennai to $87^{\circ} \mathrm{E}$ during 10-12 \&16-18 August 1999

Figure 2. Vertical section of temperature along $13^{\circ} \mathrm{N}$ for the two transects.

away from the coast. The vertical extent of this cold core eddy lies between the surface and more than $500 \mathrm{~m}$ depth. The rate of dissipation of temperature and salinity from transect one to transect two after a period of 4 days showed that ridge structure reduced $6 \mathrm{~m}$ per day in temperature and $2.5 \mathrm{~m} /$ day in salinity fields. From these dissipation rates if one indirectly computes the periodicity of a propagating wave, it is possible to infer the presence of long period waves around 16 to 24 days.

Under the influence of this eddy the mixed layer exhibits variations from west to east. The thermocline and its gradients also showed large variation. Relatively high salinity cells around 34.9 PSU were noticed below $200 \mathrm{~m}$ depth east of $100 \mathrm{~km}$ away from the coast. The thermal and salinity gradients were very weak below $100 \mathrm{~m}$ (Gopalakrishna et al 1996).

As mentioned in the introduction, oceanic eddies are generally formed either by separation of a meander or due to the force exerted by the wind stress curl and maintained by the balance between the pressure gradient, centrifugal and coriolis forces, or due to the westward propagation of long period Rossby waves. The Bay of Bengal influenced by the seasonal reversing monsoon and cyclonic storms and fresh water discharges is dominated by oceanic eddies. TOPEX altimeter observations show several eddies in the Bay of Bengal almost throughout the year (Ali et al 1998). The geostrophic flow regime was dominated by the presence of eddies. The dome shaped temperature contours near the east coast of India at $14^{\circ} \mathrm{N}$ indicate the presence of a cyclonic eddy about $200 \mathrm{~km}$ in diameter (Sanilkumar et al 1997). Murty et al (1993) reported eddy at $12^{\circ} \mathrm{N}$ near the east coast of India. Babu et al (1991) have reported the presence of a cyclonic eddy in the northern Bay.

Recent investigations in the Bay of Bengal (Gopalan et al 2000 and Babu et al 1991) also 


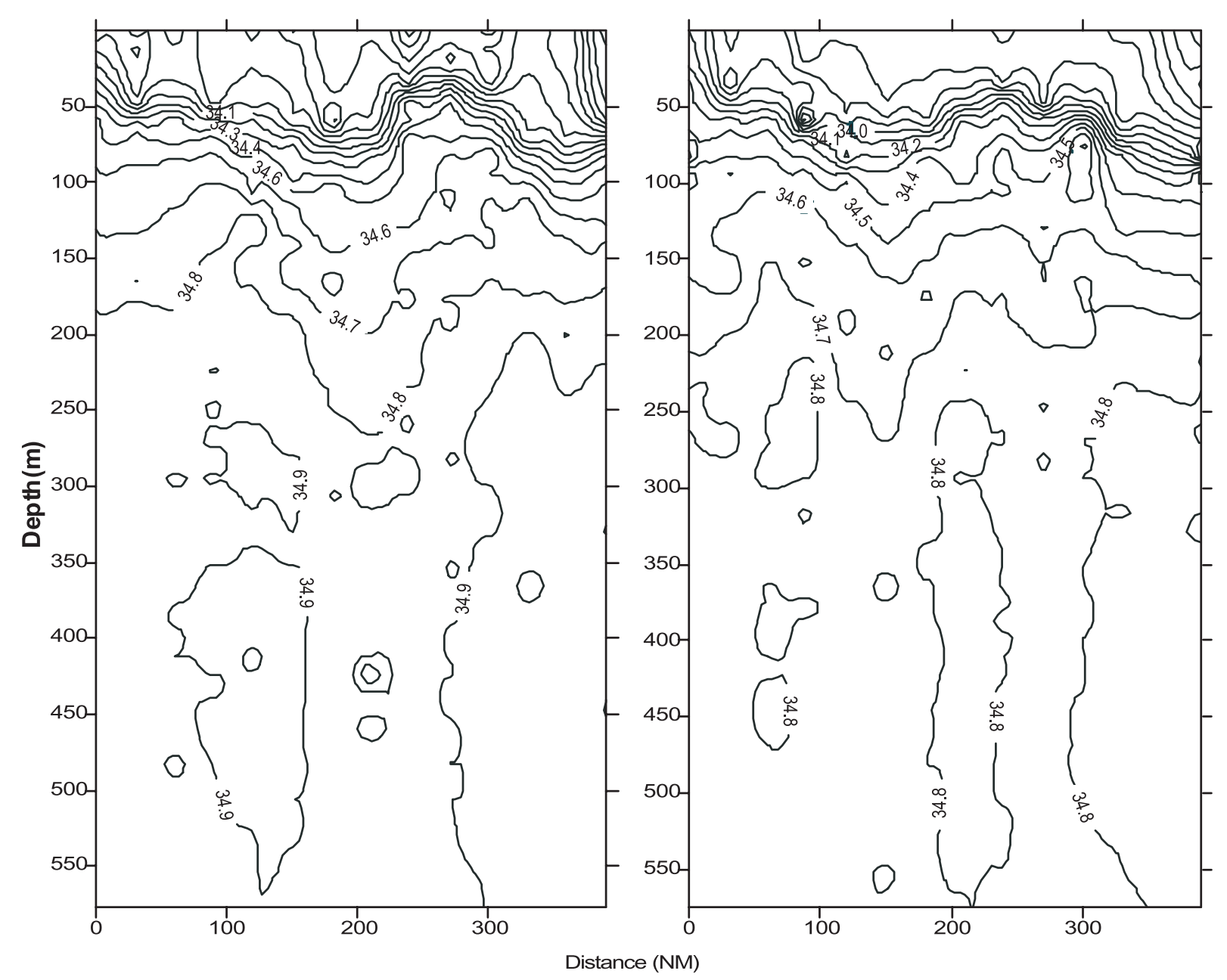

Vertical sections of salinity(PSU) along $13^{\circ} \mathrm{N}$ from Chennai to $87^{\circ} \mathrm{E}$
during $10-12 \& 16-18$ August 1999

Figure 3. Vertical sections of salinity along $13^{\circ} \mathrm{N}$ for the two transects.

support the present findings of the cyclonic eddy between Chennai and Andaman. Snapshots of thermal structures along the Chennai-Andaman XBT sections during 14th-16th August 1993, 9th-11th August 1994, 26th-28th August 1995 and 17th19th August 1996 also exhibit a cyclonic eddy near the same area. Sea Surface Height (SSH) observations derived from TOPEX altimeter observations during August 11th-20th, 1993, August 5th14th, 1994, August 22nd-31st, 1995 and August 14th-23rd, 1996 over the Bay of Bengal revealed cyclonic eddies with a depression of 15 to $20 \mathrm{~cm}$ centered around $14^{\circ} \mathrm{N}$ and $85^{\circ} \mathrm{E}$ (Gopalan et al 2000).

Analysis of TOPEX/Poseidon data during the BOBMEX period reveals several eddies in the Bay of Bengal. There also we found a cyclonic eddy around $13^{\circ} \mathrm{N}$ and $85^{\circ} \mathrm{E}$ with a depression of $\mathrm{SSH}$ around $12-15 \mathrm{~cm}$. Gopalan et al (2000) have used both temperature and TOPEX/Poseidon data to document eddies in the Bay of Bengal. They also noted a subsurface ridge in the temperature section and a depression of SSH of about 15-20 cm near $13^{\circ} \mathrm{N}$ and $85^{\circ} \mathrm{E}$ in the TOPEX/Poseidon analysis. When the upward motion of water occurs, it diverges at the surface creating a depression in SSH because of the cold dense water at the surface. This can be seen from the upsloping of $28^{\circ} \mathrm{C}$ isotherm almost at the surface of the ocean at $13^{\circ} \mathrm{N}$ and $85^{\circ} \mathrm{E}$.

A scan through the wind field in the area during the study period indicated a break monsoon with wind speed less than $7 \mathrm{~m} / \mathrm{sec}$ with variable wind direction. Hence, surface wind cannot be taken as a causative factor for the formation of the eddy. From the dissipation rate the role of long period wave can be considered. Kelvin waves are found to be generated in the equatorial region as the result of local wind forcing (Potemra et al 1991; Yu et al 1991). These waves move eastward and reflect towards the 
north along the eastern boundary of the Bay. While traveling northward, these coastal Kelvin waves radiate long Rossby waves, which propagate westward. These westward propagating Rossby waves in the Bay of Bengal may cause the observed undulations noticed in the vertical sections. Hence the ridge structure noticed in the vertical sections may be due to these westward propagating Rossby waves.

The spectral analysis of currents in the Bay of Bengal by Potemra et al (1991) suggested the presence of oscillations of 20 to 30 day periodicity and attributed it to long period Rossby waves excited by remote-forced Kelvin waves. Winds, currents, air temperature and SST collected from the moored buoy near $13^{\circ} \mathrm{N}, 87^{\circ} \mathrm{E}$ during 19th July to 23rd September 1999 were subjected to spectral analysis (Hareesh Kumar et al 2001) and the results revealed the presence of intra-seasonal oscillations of 10 to 32 days. Hence, the subsurface cyclonic eddy may be due to the presence of westward propagating Rossby waves in the Bay of Bengal.

\section{Conclusions}

- From the temperature and salinity sections, it is found that the central Bay of Bengal at $87^{\circ} \mathrm{E}$ appears to be warmer $\left(0.2-0.4^{\circ} \mathrm{C}\right)$ and more saline (0.85 PSU) compared to the western Bay. The thickness of the thermocline is around 30$40 \mathrm{~m}$ and halocline is about $20-30 \mathrm{~m}$ and lies in the upper $100 \mathrm{~m}$.

- An interesting feature in the temperature and salinity fields is the presence of a cyclonic eddy with a spatial scale of the order of $100-150 \mathrm{~km}$ around $280 \mathrm{~km}$ away from the coast. The mixed layer depth shoaled to $10 \mathrm{~m}$ in the first transect and $30 \mathrm{~m}$ in the second transect because of this eddy.

- From the analysis of the dissipation rate from transect one to transect two and the analysis of the TOPEX data, it may be inferred that the cyclonic eddy is possibly due to the presence of westward propagating Rossby waves in the Bay of Bengal.

\section{Acknowledgements}

We are grateful to the Director, Naval Physical and Oceanographic Laboratory, Kochi for the encouragement provided. We are also grateful to the organizers and participants of the BOBMEX programme.

\section{References}

Ali M M, Sharma R and Cheney R 1998 An atlas of the north Indian Ocean eddies from TOPEX altimeter derived sea surface heights; Indian Space Research Organization, Special Report.

Babu M T, Prasanna Kumar S and Rao D P 1991 A subsurface cyclonic eddy in the Bay of Bengal; J. Mar. Res. 49 404-410

Gopalan A K S, Gopala Krishna V V, Ali M M and Sharma Rashmi 2000 Detection of Bay of Bengal eddies from TOPEX and in situ observations; J. Mar. Res. 58 721734

Gopalakrishna V V, Pedneker S M and Murty V S N 1996. $\mathrm{T}-\mathrm{S}$ variability and volume transports in the central Bay of Bengal during southwest monsoon; Indian J. Mar. Sci. 25 50-55

Hareesh Kumar P V, Prasada Rao C V K, Swain J and Madhusoodanan P 2001 Intra-seasonal oscillations in the central Bay of Bengal during summer monsoon 1999; Curr. Sci. 80 No. 6, 786-790

Murty V S N, Suryanarayana A and Rao D P 1993 Current structure and volume transport across $12^{\circ} \mathrm{N}$ in the Bay of Bengal; Indian J. Mar. Sci. 22 12-16

Potemra J T, Luther M E and O'Brien J J 1991 The seasonal circulation of the upper ocean in the Bay of Bengal; $J$. Geophys. Res. 96 12667-12683

Sanilkumar K V, Kuruvilla T V, Joggendhranath D and Rao R R 1997 Observation of the western boundary current of the Bay of Bengal from a hydrographic survey during March 1993, Deep Sea Res. 44 135-145

Shetye S R, Gouveia A D, Shenoi S S C, Sunder D, Michael G S and Nampoothiri G 1993 The western boundary current of the seasonal subtropical gyre in the Bay of Bengal; J. Geophys. Res. 98 945-954

Yu L, O'Brien J J and Yang J 1991 On the remote forcing of the circulation in the Bay of Bengal; J Geophys. Res. 96 20449-20454 